\title{
Examination Management And Examination Malpractice: The Nexus
}

\author{
James A. Ogunji, Babcock University, Nigeria
}

\begin{abstract}
Examination malpractice or cheating has become a global phenomenon. In different countries of the world today, developed and developing, academic dishonesty especially cheating in examinations has heightened and taken frightening dimension. In many countries of the world this phenomenon has become a serious matter of concern that has left many appalled and conjecturing the cause of this problem. This paper implicates unethical examination management practices which begin from teaching in the classroom, thereby shifting the usual focus of examination malpractice on students to the entire chain of examination management process. This implies that teachers, school heads, administrators, invigilators, supervisors, examiners, secretaries or clerks, examination bodies, parents, and law enforcement agents are part of this problem. The paper thus theorized about global examination malpractice that; the magnitude of examination malpractice in any country at any time is directly proportional to the extent to which examination management roles violate or uphold examination ethics. Using Nigeria as a point of reference, this paper discusses the unethical examination management practices that tend to sustain examination malpractice. It further articulates examination management ethics, which when followed can check the tide of cheating in examinations.
\end{abstract}

Keywords: Examination Management; Examination Malpractice; Nexus

\section{INTRODUCTION}

Problem Analysis

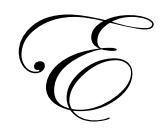

xamination is one of the major means of assessing and evaluating students or learners skills, knowledge and attitude in both general and specific areas of studies. It is a crucial mode of assessment of the learner's mastery of certain required quantum or corpus of knowledge. Be it school tests, university examinations, professional certifications, cheating seem to be the watch word across the globe. Cheating in examinations are evident in developed and developing countries but the security regulations and means of implementing them are not universally provided and often ineffective ((Eckstein,2003).

Since 1991 in Nigeria, examination cheating can be said to have taken incredible and sophisticated dimension in both secondary and tertiary educational institutions. Adenipekun (2004) has the following details about examination malpractice in Nigeria:

Each year for example the five major examination bodies (JAMB, WAEC, NECO, NABTEB, and NTI) cancel an average of 740,000 result on account of massive malpractice. An average of 450 principals, supervisors, invigilators and examiners are blacklisted for their involvement in abetting exam malpractice each year. About 9000 students are handed to the police at various centers each year. A whopping sum of N17 billion is wasted every year in registration forms to retake those examinations.

No doubt that in Nigeria examination malpractice has "attained frighteningly sophisticated proportions and is a little short of being institutionalized. Efforts by governments at all levels and stakeholders in the educational sector to curtail the ugly trend have not yielded much fruit." (Saintmoses, 2008). Hence examinations in schools at all levels have been trailed and marred by scandal of fraud and irregularities. Literature on examination malpractice 
also tend to show that a handful of students and teachers do not know what constitute examination malpractice and ethics (Ogunji and Abidoye, 2005, Donald McCabe et.al 1999, Azuka and Alutu, 2006).

The examination malpractice scourge has rekindled both international and national discussion on the causes and what can be done to contain, or reverse the trend. This paper maintains that unethical examination management practices is key in sustaining examination malpractice by threatening examination security and rendering examination regulations ineffective. It is emphatic on the point that the menace of examination malpractice globally is directly proportional to the lack of integrity and unethical behavior of examination managers. It reviews the specific ways examination management practices connect with examination malpractice and create enabling environment for it. The paper further outlines examination management ethics, for teachers, students and parents, which when followed are expected to check examination cheating in any educational system.

\section{Scope of the study}

The study focuses on examination malpractice as a global phenomenon, with specific emphasis on examination management and examination malpractice in Nigeria educational system.

\section{Objective of the study}

The objectives of the study include:

1. To highlight examination malpractice or cheating as a global phenomenon

2. To identify through a model the unethical examination management practices that tend to sustain examination cheating using Nigeria as a point of reference.

3. To identify and formulate the ethics of examination management especially for roles in examination management such as; teachers, administrators, supervisors, exam bodies, parents, government and students,

\section{Clarification of terms}

Examination Management: Examination management is the process or act of planning, organizing and administration of an examination. In this paper examination management include and may not be limited to; school administrators, examination bodies, teachers, invigilators and law enforcement agents among others. Examination malpractice or cheating: This is the abuse of rules and regulations pertaining to internal and public examinations, their marking and grading, to the release of the result and issuance of certificates (Nwana, 2000). It is also referred to mean cheating in examination as a form of academic dishonesty. In this paper examination malpractice refers to cheating in examination which is any attempt to give or obtain unauthorized assistance in an examination. The terms examination malpractice or cheating is used interchangeably. Nexus is a means of connection; link; bond (Collins, 2006). In this paper unethical examination management practices is seen as the bond that sustains cheating or examination malpractice.

\section{LITERATURE REVIEW: EXAMINATION MALPRACTICE AS A GLOBAL PHENOMENON}

From Africa to Europe and to America, the issue of examination malpractice, or academic dishonesty has become a concern for educators. Czek (2000) was right when he found that cheating is a global phenomenon, with little cultural variations. He noted that "wherever the stakes are high and there is an advantage and opportunity to cheat, it seems to happen." Among his findings is that 3-5\% examination candidates are likely to be cheating with almost none of these pupils being caught.

Even teachers are known to be involved in examination malpractices by allowing their pupils to see questions in advance, correcting answers, and outright given them answers (Czek, 2000). Commenting on examination malpractice in Ghana, Annan (2005) said examination malpractices have assumed an alarming trend in recent times. Mize, C., Rogers, K. \& Gibbons, A. (2002) noted that the problem of cheating, or academic dishonesty as some colleges refer to it, is not a new problem in America. Noting that "ever since there have been exams to cheat on, papers to plagiarize, and homework to be copied, it has been done". They acknowledge that 
cheating among students in America is on the rise in the past 60 years and that cheat has evolved just as the world's technology has. They further revealed that a recent survey found that $80 \%$ of the top students listed in the Who's Who in American Schools admitted to cheating. This constitutes the highest percentage in the survey's 29 year history.

In the same vein Clayton (1999), says cheating has become a major topic at faculty meetings on college campuses across America. It has kept administrators and universities scratching their heads wondering why there has been an increase in academic dishonesty over the past years.

Equally of note is the 1990, 1992 and 1995, study by McCabe (1999) of the Center for Academic Integrity (CAI) in Nashville USA. About 7,000 students from 26 small-to-medium-size college campuses were surveyed. It was found that nearly 80 percent of the students surveyed admitted to cheating at least once. McCabe describes the findings as "a dramatic increase in the more-explicit forms of test cheating and illegitimate collaboration" (pp. 208). As Ann and William (1977) noted, academic dishonesty is endemic in all levels of education. In the United States, studies show that $20 \%$ of students started cheating in the first grade". Similarly, other studies reveal that currently in the U.S., 56\% of middle school students and 70\% of high school students have cheated (Wilfred, 2002). This means that cheating in examination starts at a lower level and works its way up.

The first scholarly studies in the 1960s of academic dishonesty in higher education found that nationally in the U.S., somewhere between 50\%-70\% of college students had cheated at least once (William, 1964). As for graduate education, a recent study found that $56 \%$ of MBA students admitted cheating, along with $54 \%$ of graduate students in engineering, $48 \%$ in education, and $45 \%$ in law (Pope, 2007).

News reports around the world give credence to examination cheating as a global phenomenon. In India separatists from the north-eastern state of Manipur shot six male teachers in the leg for allegedly helping students cheat in exams (Subir Bhaumik, BBC News). According to Conde (2006) the Philippines' nursing board examinations were leaked to hundreds of applicants. The Philippines' Professional Regulation Commission confirmed that questions in the board exams taken by more than 42,000 nursing graduates were provided in advance to hundreds of people.

From China, Frederik Balfour (2009) also reported more than 1000 hopeful candidates were caught cheating for the annual civil service exams, where 775,000 people competed for 13,500 jobs. "Some even resorted to inserting micro-receivers in their ears to receive remote coaching while sitting the tests. The numbers of cheaters nabbed this year are much higher than in the past". Even beyond the four walls of colleges and universities the situation is the same. A study by Kevin and Wirzbicki (2008) confirms widespread cheating on job examination worldwide. Out of 200,000 tests given in the eight countries that formed part of the study, about 1,400 were possible cheaters. A follow up investigation confirmed that approximately 1,000 were trying to take a certification exam for someone else.

In Seoul South Korea police arrested two men suspected of making tens of thousands of dollars by using high tech electronic devices to send real-time answers to exam cheats. The men collected money from 28 university students and job-seekers in exchange for answers to the Test of English for International Communication (TOEIC) (Straitstimes, June 24, 2009)

According to Kathleen et al (2006), two first year medical students in Luck now, India who sew a tiny microphone and speaker inside a shirt cuff, activated it on a concealed cell phone, and got their friend outside to scan the textbook for answers were caught. The paper reports that India's educators share the blame for rampant fraud, as exam questions are often leaked beforehand by insiders. It also noted that in 2003, a standardized entrance exam for six elite management schools was cancelled after students had reportedly agreed to pay up to $\$ 10,000$ per question sheet and scalpers arrested with the question paper.

Similarly, Vencat (2006) noted that the rates of academic cheating have skyrocketed during the past decade globally. In Britain, a recent government-sponsored report found such rampant cheating in the state-run GCSE and A-level exams. The report further noted that nearly all of India's ultra competitive entrance exams have been stolen 
and sold to students at least once during the past five years. In 2004 for example students paid up to $\$ 15,000$ apiece for access to answers to India's Pre-Medical Test. Also in 2005, South Korea faced the biggest exam-cheating scandal in its history. The national college-entrance exam, the CSAT, was infiltrated by more than 20 cheating rings across the country. They had text-messaged exam answers to paying students taking the test.

The literature reviewed gives credence to the fact that examination cheating or malpractice is a global phenomenon. It is such that is characteristic of all levels of education and discipline irrespective of the age group or profession involved. It is a challenge to the quality of education in many countries of the world. As such it has also become a concern of a global dimension especially with the advancement in technology, postmodern philosophy, and claimed ignorance of students and teachers on examination ethics or what constitutes examination malpractice.

\section{THEORETICAL FRAMEWORK}

This study is conceptualized based on the framework of systems theory This approach holds that an organization is a managed system that transforms inputs such as raw materials, people and other resources into outputs which is the goods and services that comprises its products (Bateman \&Snell, 2004). One of its key concepts is that management must interact with the environment to gather inputs and return the output of its production. Consequently in this study, the inputs of examination management (unethical examination management practices) interact with all the examination management roles and returns examination malpractice as the output.

\section{Model Showing the Nexus of Examination Management Practices and Examination Malpractice}

Figure I: Ogunji's Conceptual Model Showing The Nexus Between Unethical Examination Management Practices And Examination Malpractices

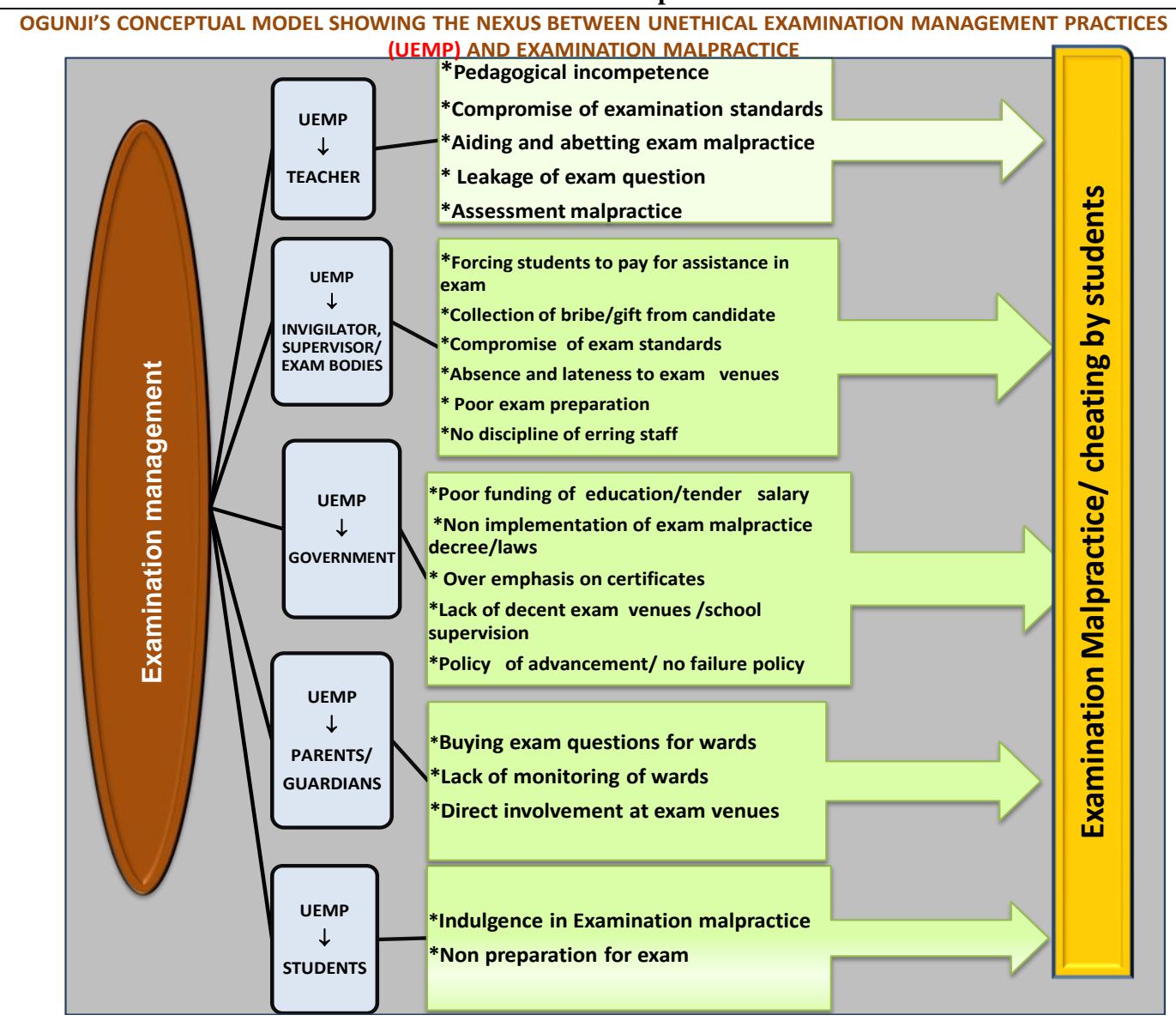


The above conceptual model illustrates the interaction between the unethical activities of the different roles in the examination management and examination malpractice. It identifies the unethical roles of the teachers, invigilators, examination administrators which include the invigilators, supervisors, teachers, examination bodies and security personnel. It is certain that at any point these unethical practices are condoned individually or collectively examination malpractice will result.

\section{MODEL DISCUSSION AND ANALYSIS}

Examination management is the process or act of planning, organizing and administration of examination. It spans from classroom teaching, setting of examination questions, administration of examination, marking or grading, to the issuance of certificate. This means that teachers, examination administrators, students, parents are part of examination management. Examination management requires marshalling and organizing all the material and human resources needed for smooth examination conduct. The quality of examination management therefore, dictates the level of malpractices or cheating in a particular examination and its occurrence or non occurrence.

In all examination malpractice or cheating, ethical standards are compromised. Rules, regulations, standards and best practices of examination conduct are overtly or covertly contravened. It is the violation of principles of good examination management by all the roles involved. Some specific and varied unethical practices of the roles in examination management which often times galvanize into malpractice or cheating are articulated below:

\section{Teachers}

\section{a). Pedagogical and Content Incompetence of Teachers}

The National Policy on Education in Nigeria (2004) stipulates that teachers at the tertiary level must have qualification in education. This is intended to improve teaching pedagogy. This policy is not widely implemented. Having mastery of subject matter without effective knowledge of teaching methodology can affect students performance. This phenomenon is the beginning of examination irregularities and misconduct. The result is that students are ill prepared for examination. Another aspect of this is assigning teachers subjects and courses that are not in their areas of competence due to mostly budgetary constraints to hire experts in the concerned areas. Due to lack of confidence and desperation to pass students may employ cheating to pass. It is an ethical requirement that a teacher should be competent in content and pedagogy. It is also unethical for a teacher to accept a subject that he or she cannot effectively handle. Teachers and school administrators are at the core of examination management process, when pedagogy and content competence of teachers are treated with levity, it creates the enabling environment for examination malpractices or cheating.

\section{b). Assessment Malpractice.}

This includes, poor question setting, allotting more or less time to an examination, testing students in areas where they are not taught, awarding of unmerited grades, error of calculation of marks, among others, misplacement of examination scripts and allocation of scores to students. All these threaten the security of examinations even when it is done discretely.

\section{c). Compromise of Examination Standards}

Teachers fan the ambers of examination malpractice when they compromise examination standards and disregard examination ethics. As Czek (2005) noted, the increasing pressures on teachers to be seen as successful, encourage them to cheat. This fact is not only true in Nigeria but in many parts of the world. There seem to be the tendency to think that when students fail in examinations the teacher has failed in his or her duties. However, pressure cannot be taken as a justification to desecrate the sanctity of examinations. Literature on examination cheating highlights the complicity of teachers in examination cheating. In Nigeria some teachers for pecuniary gains aid exam cheating in ways such as; compromising examination standards, absenteeism from attending classes due to personal businesses or due to incessant strikes, sale of own text books to students which takes place of teaching the 
students. Actions such as correcting of answers and outright giving the students the answers when marking is also cheating. Other ways some teachers are implicated in examination malpractice include leakage of examinations papers. Sex for marks, where female students especially are awarded marks arbitrarily in exchange for sexual escapades. This is dominant in colleges and universities. In addition some teachers connivance with students who are cheating by undue assistance during invigilation. These include; giving clues, facilitating undue communication among students, not confronting students who are cheating by refusal to report examination malpractice cases and by tampering with the process of prosecuting and sanctioning offenders.

\section{Invigilators and Supervisors}

a. Absence and lateness to Invigilation: Attention is hardly paid to this unethical conduct in examination management. Lateness by a teacher or invigilator to examination venues or absence from invigilation constitute examination malpractice When an invigilator is absent or late to examination venues it creates the enabling environment for cheating. Even in the examination hall invigilators read newspapers or engage in discussions that interfere with the "vigil" which is the core of invigilation. All these create enabling environment for examination malpractice to thrive, and weaken examination management process.

b. Acceptance of bribes "cooperation fee" by supervisors, invigilators, examiners and law enforcement agents. Often times the different groups who should protect the oracle of examination, compromise it by taking bribery. Students contribute money to pay them off their sacred responsibility and national assignment. With this arrangement impersonation of candidates are glossed over, parents or their paid mercenaries are allowed into the examination halls, and the atmosphere of cheating with impunity takes over in the examination venues and gross examination violations are winked at.

\section{Examination Bodies}

These include accredited bodies that set and handle examinations such as West African Examination Council (WAEC), National Examination Council (NECO). Unethical practices of such bodies sometimes include violation and disregard of examination process. Such violation and disregard for examination best practices include but may not be limited to the following:

a. Poor examination planning and logistics. This include providing unsuitable rooms, hall or examination venues resulting into crammed venues, haphazard sitting arrangements, loss of adequate control over the examinees, insufficient number of invigilators leading to overworking the few and poor invigilation, shortage of question papers and other examination materials. Often times students and candidates do not know their examination numbers and centers until the day of examination. These anomalies and lapses create the platform for cheating in examination.

b. Lack of accountability in the conduct of examination. Examination bodies do not require accountability in the conduct of examinations. The examination officials are not monitored and accountable for their activities during examinations. It has become such that they perpetrate unethical practices in examination management with impunity. At this time of writing the West African Examination Council examination for secondary school student is going on. My ward in the secondary school exam near my university Babcock University is asking from me money the school authorities and examination supervisors want them to contribute in other to be helped with the answers in critical subjects as English and Mathematics. You would be shocked to know that teachers who claim to have taught these students are the same people collecting money to supply answers in the examinations they are invigilating. It often times degenerate to the extent where answers to exam questions are written on the board for students to copy. This type of illegality cannot go on where accountability is demanded in any system. Examination bodies and schools shy away from meting appropriate discipline and sanction to erring teachers and staff in this regard. Though many school administrators gloss over this for fear of attack by those involved and the cult groups influencing the teachers, it is not a strong ground to allow the menace of examination malpractice. 


\section{Government}

The government should provide and regulate the essential service of education to its populace. Often time they unwittingly contribute to examination cheating in the following way:

a. Inability to fund education properly. The dwindling funding of the education sectors is a cardinal precursor to examination malpractice. For education Nigeria spends an estimated $2.4 \%$ of its GNP. This compares poorly with other developing economies (William et.al., 2004). It has been established that Nigeria's allocation shares for education diverge sharply from regional and international norms. With this state of affairs quality of teaching, infrastructure, governance, innovations in education sector are stifled. These have direct or indirect relationship to examination management and malpractice. Inadequate funding as evident in the nonpayment of teachers salary and allowances, have occasioned corruption in all facets of education in Nigeria. It has led to admission of more students than the carrying capacity, breakdown of infrastructure, lack of motivation of teachers and staff. All these have overt or covert effect on examination malpractice.

b. Lack of implementation of examination malpractice decree no. 33 of 1999 which stipulates 21 years imprisonment for culprits. Since this law was enacted, nobody has been convicted in spite of the monumental nature of examination malpractice among students. Though students, mercenaries, and staff of examination bodies have often been arrested offenders there seem to be no indication that prosecution has taken place ever. When the roles in examination management know that the law is not implemented it results into unrestrained cheating with impunity.

c. Policy of automatic promotion (in some states in Nigeria): the policy of continuous assessment has been taken to mean continuous advancement, where no student fails. Thus weak students are presented for examinations. Due to the desperation to pass they employ all unethical means to get ahead.

\section{Parents and Guardian}

The cooperation of parents with the school makes for success in every education endeavor be it student learning, discipline, governance, and good examination management. In the history of examination malpractice in Nigeria parents who should be part of quality examination management by de facto become part of the problems by unethical practices such as:

a. buying examination questions for their ward. Due to dire want of success for their children parents identify and pay mercenaries, and impersonators to write exams for their children and wards.

b. shamelessly providing the funds to bribe and influence teachers, staff of examination bodies, to generate fraudulent results for their wards.

c. following their children to examination hall to make sure their plans for cheating is safely executed.

d. Inability to monitor their children and ward' academic progress before they get desperate

By this they interfere with examination management, weaken the process of examination management and sow the wild seed of examination cheating.

\section{Cheating in Examination by Students}

The students are not left out in unethical practices that crystallize into examination malpractice obsession. Alarape and Onokoya (2003) were not wrong when they concluded that cheating is gradually becoming a means of getting ahead academically and is a major problem facing students today.

The unethical methods students employ include over 33 types of examination malpractice in vogue today among students captured by Adenipekun, (2004). These often times include:

a). Impersonation Method which involves hiring of mercenaries to write an exam for another person. This unethical practice has been christened "towing" and "ECOMOG" "contractor" in students circles because it involves candidates arranging with people before hand to assist them in writing examination. Students also 
bring extraneous materials stored in pieces of papers into the exam which is called the microchip method. Some of the methods employed under this practice include prepared notes and materials written on palms, thighs, textbooks, and gadgets designed to assist them to pass the examination instead of relying on their own abilities.

b). At other times group of students colonize a section of the examination room by seating in section they have agreed with those who know the course very well known as "power house" who will "pass the current" to the rest. The sorting method is the one in which student meet teachers, invigilators, before or after examination to influence them to their advantage in cash or in kind. Also, they adopt the "wholesale method" of coming into the examination with answer scripts or booklet written or answered before the examination.

c). They are also involved in the use of telephone handset GSM to send text massages of answers to friends in different centers.

d). Anan (2005) noted other unwholesome developments inside and outside the examination halls which boarder on stealing of people's work, converting or misappropriating the scripts of other candidates, substitution of scripts at the end of the examination, tearing answer scripts for the examination papers only to complain later that their scripts.

\section{EXAMINATION MANAGEMENT ETHICS}

If you ask anybody what ethics means, you are likely to hear that it has to do with moral judgment or right actions. Etymologically, the word ethics is based on the Greek word "ethos" which means character or what a good person is or does in order to have good character. Black et. al (1999) say that it deals with what obligation we owe or to responsibilities we have toward our fellow humans, and what we should do to make the world a better place than we find it. In determining examination management behavior that are ethical two questions must be asked and answered. What must one do? And what must one not do? The definition of ethics by Dominic (1996) is therefore worthy of note; "ethics are rules of conduct or principles of morality that point us toward the right or best way to act in a situation."

For the purpose of this paper, ethics is conceptualized to be the expected behavior of the teachers, administrators, examination bodies, students, law enforcement agents and others who are actors in examination management in both internal and external examinations. It is also taken as the moral principles that should control or influence the behavior of all roles of examination management. Four core roles involved in examination management are however addressed; teachers, student and examination administrators and government. In many colleges and universities' bulletin and academic documents, mention is made of academic integrity and honesty, but the details of what constitute that are not usually mentioned. It seems to be taken for granted that people know what constitute ethical examination practices. Yet literature in this regard is otherwise. Studies done on determining the knowledge of students on examination ethics show that many students do not know what constitute examination malpractice or cheating (Azuka and Oyazuwo, 1999). That is why it is auspicious to articulate what exactly can constitute ethical examination practice. An attempt is in this regard in this section of the paper.

\section{Examination Ethics for Teachers} following:

The expected behavior (ethics) of teachers in this regard will include but may not be limited to the

a. Developing new skills and improving on the instructional process. This gives students/learners confidence to face examination as opposed to when the feel inadequate and desperate to pass by hook or crook. Examination is cardinal to assessment of students. Assessment is not a separate activity from instruction or teaching. The management of examination starts from teaching

b. Maintaining and enforcing the integrity of the examination process. The teacher is a critical element in the education enterprise. They not only teach but are examination administrators, invigilators, and supervisors. It is therefore their professional role to maintain the sanctity of examinations. Not doing this responsibly is sabotaging own effort and self destruction.

c. Setting question in line with instructional objectives and content covered 
d. Acquainting students/learners with examination code of conduct and ethics of their institutions and;

e. Being fair to all students

f. Desist from compromising the integrity of examination by receiving gratification from students, in cash or in kind

\section{Examination Management Ethics for Supervisors/Administrators}

Examination administrators have the onerous task of making the examination management process work effectively. Their core work is to create the enabling environment for the smooth conduct of examinations. To this end the right or best way those involved in exam management are to act (ethics) include but may not be limited to the following:

a. Timely production of individual time table for staff, students and examination administrators. The invigilation schedule should be made available to supervisors for adequate preparation and readiness at least. It is also important to conduct pre-examination orientation and briefing for all examination administrators, support staff and students/candidates. This is where the examination regulation and code of conduct can be communicated to the students/candidates and staff. Where it is difficult to reach candidates on one-to-one basis as in the case of most external examinations, the mass media should be employed for public announcements, notices.

b. Provision of facilities, materials and resources needed for examination. These are the logistics that create the environment for malpractice when they are not well taken care of. Adequate examination materials, specimen, seats, invigilators, security, refreshments should be provided and necessary arrangement made to fill unforeseen gaps.

c. Maintaining the highest standards of ethics and integrity in examination conduct and enforcing them. The examination bodies and administrators must be responsible enough to live up to its bidding. It is incomprehensible that the examination administrators charged with ensuring best practices in its conduct sometimes contribute to entrenching unethical practices as afore mentioned. Moreover, training of supervisors and examination management staff is a determining factor to high standard of ethics

d. School administrators, examination bodies should handle cases of examination malpractice seriously. Offenders must be prosecuted and disciplined accordingly to serve as deterrent to intending offenders.

e. Security/ confidentiality of the examination.

\section{Examination Ethics for Government}

The government creates the systemic environment for combating examination malpractice in country. In a country as Nigeria the ethical thing the government can do to check the astronomical tide of cheating in examinations include but not limited to the following:

a. Adequate funding of schools. This is critical because it is the index of quality education.

b. $\quad$ Enforcement of examination malpractice decrees and laws

c. Blacklisting of schools involved in examination malpractice.

d. Requiring adequate school supervision from ministry of education

e. Improving and prompt payment of teachers salary

f. Maintaining the stability of school calendar so as not to disrupt the teaching and learning process.

g. Appointment of efficient and leaders with integrity for schools

\section{Examination Ethics for Parents}

Parents may not be considered as being directly involved in the examination management process. However, they have serious role to play as the guardian and financiers of students in most cases. Their ethical or expected role in examinations may include but not limited to the following:

a. Pay up wards examination fees and make sure he or she is well registered for the examination to be seated for. 
b. Monitor your ward preparation studying $\mathrm{n}$ especially reading for the examination and provide needed books and equipment.

c. Do not hire mercenaries for your ward or be part of any arrangement that facilitate cheating in examination.

d. Do not follow your ward to the examination venue

e. $\quad$ Buy the needed text books and support your ward to prepare well for each examination

f. Take personal responsibility to protect the integrity of examination

g. Lead your ward by example

\section{Examination Ethics for Students}

Students are at the center of examination management. They are the ones who are instructed and examined. It is true that the major preoccupation of students/learners during any examination is to pass. However, their role in the process of examination management is very important. The ethical or expected behavior of a student will include but may not be limited to the following:

a. Thorough acquisition of knowledge expected in the different subjects to be examined. It is the responsibility of the students to have mastery of subject matter prepare adequately for examination. When such preparation is lacking it breeds fear and lack of confidence which may make the students vulnerable to examination malpractice.

b. $\quad$ Check and have the final time table of each examination

c. Confirm all information of any change on the time table from the examination secretariat, administrators and responsible teachers

d. Be conversant with code of ethics and conduct governing every examination

e. $\quad$ Protect his/her question paper, answer scripts or booklet

f. Respect the invigilators, supervisors, examiners and other examination authorities

g. Locate examination hall, room, or center some time before examination starts

h. Be punctual to examination venues

i. $\quad$ Determine to face the examination personally and not rely on any fraudulent approach

j. $\quad$ Not cheat a little even if not found out

k. Follow all examinations rules and guidelines to the letter.

1. Trusting in God

\section{CONCLUSION}

Examination malpractice or cheating is no doubt a global phenomenon which is on the increase in recent times. As a matter of fact, many students seem to get ahead through cheating in examination even in prestigious examinations. Nigeria as a nation has witnessed an alarming crisis of examination cheating in secondary and tertiary institutions. This ugly trend is sustained by unethical practices of those in the examination management process, which includes; teachers, school administrators, examination administrators, parents, and students. Such practices as; pedagogical and content incompetence of teachers, undue assistance of students by teachers, violation, and disregard of examination rules among others is the nexus of examination management and examination malpractice. For examination cheating to be reversed all the roles in examination management should abide strictly with ethical code of examination conduct. It can therefore be theorized about global examination malpractice that the magnitude of examination malpractice in any country at any time is directly proportional to the extent to which examination management roles violate or uphold examination ethics. Every examination malpractice is a product of the violation of examination ethics or that of unethical examination practice.

\section{AUTHOR INFORMATION}

James A. Ogunji, Department of Education and General Studies, Babcock University, Nigeria. E-mail: ogunjija@yahoo.com 


\section{REFERENCES}

1. Adenipekun, O. (2004, March 4). Exam malpractice now multibillion naira business. Vanguard. Retrieved July 10, 2009 from website: http://www.sdnetwork.kabissa.org

2. Alarape A.I and Onokoya A.Y. (2003). Correlates of examination cheating behaviour among university students. IFE Psychologia 11(1), 71-79.

3. Alleged Exam Cheats Caught (2009 June 24) Straitstimes Retrieved from Retrieved from http://www.straitstimes.com/Breaking\%2BNews/Asia/Story/STIStory_394744.html

4. Annan, R. (2005 April). Dangers of examination malpractice. A GNA Feature Retrieved from http://www.ask.com/bar?q=examination+malpractice $+\&$ page $=2 \& q s r c=2417 \& a b=2 \& u=h t t p \% 3 \mathrm{~A} \% 2 \mathrm{~F} \% 2 \mathrm{~F}$ www.ghanaweb.com\%2FGhanaHomePage

5. $\quad$ Ann, B. \& William R. N.(1977). School cheating behavior, Review of Educational Research 47(4), 623.

6. Azuka, N.G. \& Oyazuwo, A. (2006). Secondary school students' perception of examination and examination ethics. Journal of Human Ecology 20(4) 295-300.

7. Bateman, T.S. \& Snell, A.S.(2004). Management the new competitive landscape. New York: McGraw Hill

8. Black, J., Bob, S., \& Ralph, B. (1999). Doing ethics in journalism: A handbook with case studies ( $3^{\text {rd }}$ ed.). Boston: Allyn and Bacon.

9. Clark N. and Robert S. (2004). "Education in Nigeria" World Education News and Reviews, Retrieved from http//www.wes.org/ewenr/PF/04Sept/PFPractical,htm.

10. Clayton, M. (1999, January) A Whole Lot of Cheatin' Going On, Christian Science Monitor, pp.208

11. Collins English Dictionary (2006). Harper Collins Publisher "nexus"

12. Conde, C.H. (August, 21,2006) Asia Pacific Scandal Over Nurses' New York Times, Retrieved from Retrieved from http://www.nytimes.com/2006/08/21/world/asia/21nurses.html?_r=1

13. Czek, G. (2000, February 5). "Cheats stay one step ahead", Education Saturday BBC News Online: 6.38 GMT

14. Dominic, J.R. (1999). The dynamics of mass communication. ( $6^{\text {th }}$ ed). Boston: McGraw Hill College.

15. Eckstein, M.A. (2003). Combating academic fraud: Towards a culture of integrity. Retrieved from Retrieved from www.unesco.org.iiep

16. Eckstein, M.A.\& Nvah, H.J (2001) "Fraud and education the worm in the apple" Retrieved from www.unesco.org.iiep

17. Frederik B.(January 20, 2009). "1000 Caught cheating on China civil service exams" Retrieved from http://www.businessweek.com/globalbiz/blog/eyeonasia/archives/2009/01/1000_caught_che.html

18. Kathleen M., Anuj, C.Hopra, Bennett R., \& Simon M. (June 15, 2006) "tech cheating" The Christian Science Monitor. Retrieved from http://www.usatoday.com/tech/news/2006-06-08-tech-cheating

19. Kevin, B. and Wirzbicki, (July 22, 2008 ). The Boston Globe, The New York Times Company

20. McCabe, D.L.;Linda K. T., and Kenneth D. B. (1999 March-April,) Academic integrity in honor code and non-honor code environments: A qualitative investigation, The Journal of Higher Education 70, no. 2, 213.

21. Mize, C., Rogers, K. \& Gibbons, A. (2002). That's My Story and I'm Sticking to It: Promoting Academic Integrity in the Online Environment. In P. Barker \& S. Rebelsky (Eds.), Proceedings of World Conference on Educational Multimedia, Hypermedia and Telecommunications 2002 (pp. 604-609). Chesapeake, VA: AACE.

22. National Policy on Education (2004) Lagos: National Educational Research Development Center (NERDC)

23. Nwana O.C. (2000). Aberration in the Nigerian Education System. UNESCO Abuja Office Nigeria.

24. Ogunji, J.A. and Abidoye, G.O.(2005) Prevalance, perceptions, precursors and prescription for examination malpractice in Higher Education:Case study of Babcock University. Babcock University Academic Congregation Colloquium Series vol. pp.74-81

25. Pope Justin,( May 19, 2007) "Higher Education sees rise in dishonesty" Associated Press

26. Saintmoses Eremosele (May 122008 ) "Taming the menace of examination malpractice in Nigeria" Retrieved from http://www.tigweb.org/youth.media/panaroma/article.html

27. Subir B. BBC News, Calcutta Retrieved from http://news.bbc.co.uk/2/hi/south_asia/4045075.stm

28. Vencat, E.F (March 27, 2006 ) Newsweek International Retrieved from http://www.msnbc.msn/id/11904737//newsweek

29. Wilfried D., (2002). Crisis on Campus: Confronting Academic Misconduct. Cambridge, Mass.: MIT Press 
30. William, J.B. (1964). Students dishonesty and its control in colleges. New York: Bureau of Applied Social Research Columbia University p115

31. William S., Teresa A.H, and Erich S. (2004). Higher Education in Nigeria: A Status Report. World Education News and Review. Retrieved from http://www.wes.org/ewenr/PF/o4sept/PFFeature.htm

\section{NOTES}

